\title{
Lung function changes after allogenic bone marrow transplantation
}

\author{
H LINK, U REINHARD, M BLAUROCK, P OSTENDORF \\ From Internal Medicine Sections II and III, Medizinische Universitätsklinik Tübingen, Tübingen, Federal \\ Republic of Germany
}

ABSTRACT The lung function of 21 patients with leukaemia (11 with acute myeloid leukaemia, six with acute lymphatic leukaemia, four with chronic myeloid leukaemia) and of five with severe aplastic anaemia was tested before and after allogenic bone marrow transplantation. Vital capacity (VC) was lowered in patients with leukaemia before transplantation. VC and FEV ${ }_{1}$ fell significantly after transplantation. Residual volume (RV) and RV as a percentage of total lung capacity (RV\% TLC) were already increased and rose significantly after transplantation. Patients with severe aplastic anaemia had noticeably increased RV and RV \% TLC, values that did not change after transplantation. In contrast to the patients with aplastic anaemia, the patients with leukaemia had significantly reduced VC, RV, RV \% TLC, and $\mathrm{FEV}_{1}$ before and after transplantation. The specific airway resistance (sRaw) was raised significantly before and after transplantation in the leukaemic patients. In addition, transfer coefficient $(\mathrm{KCO})$ fell significantly more after transplantation in the patients with leukaemia than in those with severe aplastic anaemia. In three patients with histologically established obstructive bronchiolitis in conjunction with chronic graft versus host disease after transplantation, VC, FEV ${ }_{1}$ and $\mathrm{FEV}_{1} \% \mathrm{VC}$ fell, while RV, RV \% TLC, and sRaw rose; KCO was far below normal. On the basis of these findings it is concluded that in patients with leukaemia obstructive disorders of ventilation develop or, if they are already present, worsen. In patients with severe aplastic anaemia lung function was not impaired in the early phase after transplantation. These differences are probably due to the more intensive immunosuppressive and cytotoxic preparatory regimen before transplantation in the leukaemic patients. Obstructive bronchiolitis, a complication of graft versus host disease, first manifests itself in a typical rise in specific airway resistance and must be treated early.

Bone marrow transplantation for the treatment of haematological disorders leads to lung diseases in over half of all patients. ${ }^{1-4}$ Such pulmonary diseases are the most common lethal complications of this form of treatment. ${ }^{23}$ In addition to pneumonia, restrictive and obstructive lung function changes have been described after transplantation. ${ }^{56}$ An obstructive bronchiolitis of uncertain pathological origin but correlated with chronic graft versus host disease has been reported by several transplantation centres. ${ }^{7-10}$ Finally, a reduction in transfer factor (diffusing capacity) after transplantation has also been described. ${ }^{11112}$

Address for reprint requests: Dr Hartmut Link, Medizinische Hochschule Hannover, Abteilung Hämatologie-Onkologie, KonstantyGutschow-Strasse 8, D-3000 Hannover 61, Federal Republic of Germany.

Accepted 28 April 1986
For these reasons we examined the lung functions 0 of 26 patients before and after bone marrow transplantation and compared the results obtained in 의 patients with leukaemia with those from patients with $>$ severe aplastic anaemia. Special attention was paid을 to cases where obstructive bronchiolitis was alsoñ present.

\section{Methods}

PATIENTS

Twenty six patients (10 female) aged from 6 to $29 \overbrace{\overparen{C}}^{\circ}$ (median 19) years were examined. The diagnoses? were: acute leukaemia in remission (16 patients) or in 0 relapse (one patient), chronic myeloid leukaemia (four patients), and severe aplastic anaemia (five patients). Details are given in table 1 . All received $\overrightarrow{\mathbb{Q}}$ bone marrow from siblings who were completelyo matched in the HLA-A, B, C, DR system and whose 
Table 1 Clinical features of 26 patients treated by allogenic bone marrow transplantation (BMT)

\begin{tabular}{|c|c|c|c|c|c|c|c|c|c|c|}
\hline & \multicolumn{3}{|l|}{$A M L$} & \multicolumn{3}{|l|}{$A L L$} & \multirow[t]{2}{*}{$S A A$} & \multicolumn{2}{|l|}{$C M L$} & \multirow[t]{2}{*}{ Total } \\
\hline & ICR & $2 C R$ & PR/Rel & $2 C R$ & $3 C R$ & Rel & & $C P$ & $A c c$ & \\
\hline $\begin{array}{l}\text { No of patients } \\
\text { Total body irradiation }\end{array}$ & 5 & 5 & 1 & 3 & 1 & 2 & 5 & 3 & 1 & 26 \\
\hline $\begin{array}{l}3 \mathrm{~Gy} \\
10 \mathrm{~Gy} \\
5 \times 2.5 \mathrm{~Gy} \\
\text { GvHD prophylaxis }\end{array}$ & 5 & $\begin{array}{l}4 \\
1\end{array}$ & 1 & 3 & 1 & 2 & 2 & $\begin{array}{l}2 \\
2\end{array}$ & & $\begin{array}{l}2 \\
15 \\
6\end{array}$ \\
\hline $\begin{array}{l}\text { Methotrexate } \\
\text { Cyclosporin A } \\
\text { Acute GvHD }\end{array}$ & 4 & $\begin{array}{l}4 \\
1\end{array}$ & 1 & 2 & 1 & $\begin{array}{l}1 \\
1\end{array}$ & $\begin{array}{l}2 \\
3\end{array}$ & $\begin{array}{l}1 \\
3\end{array}$ & 1 & $\begin{array}{r}16 \\
9\end{array}$ \\
\hline $\begin{array}{l}\text { O-I } \\
\text { II-IV }\end{array}$ & $\begin{array}{l}1 \\
1\end{array}$ & 3 & 1 & 1 & 1 & $\begin{array}{l}1 \\
1\end{array}$ & $\begin{array}{l}3 \\
1\end{array}$ & 3 & & $\begin{array}{r}12 \\
5\end{array}$ \\
\hline Chronic GvHD & & & & & & & & & & \\
\hline $\begin{array}{l}\text { Limited } \\
\text { Extensive }\end{array}$ & 2 & 1 & & & 1 & 1 & & & & $\begin{array}{l}3 \\
6\end{array}$ \\
\hline Lung disease after BMT & $\begin{array}{l}\text { BFOV*/ } \\
\text { F/F }\end{array}$ & IF/BR/ & BF & IF & $\mathrm{F}^{*}$ & & B & BOV* $^{*} /$ & & \\
\hline Relapse after BMT & 1 & 3 & & 3 & & 2 & & & & 9 \\
\hline
\end{tabular}

*Fatal outcome; patients with two or more symbols had more than one episode of pulmonary disease.

GvHD - graft versus host disease; AML - acute myeloid leukaemia; ALL - acute lymphoblastic leukaemia; CR-complete remission; PR - partial remission 5 Rel-relapse; SAA - severe aplastic anaemia; CML —chronic myeloid leukaemia; CP—chronic phase; Acc-accelerated phase.

Lung diseases: B-bacterial pneumonia, F-fungal pneumonia; V-viral pneumonia; O-obstructive bronchiolitis; IF-pulmonary infiltrate of unknown origin; BR-bronchitis.

Conversion: SI to traditional units-Radiation dose: $1 \mathrm{~Gy}=100$ rads.

lymphocytes gave no reaction in mixed lymphocyte culture.

\section{CONDITIONING AND BONE MARROW \\ TRANSPLANTATION}

Patients with leukaemia were given two doses of cyclophosphamide $60 \mathrm{mg} / \mathrm{kg}$ body weight to destroy leukaemic cells and to produce immune suppression. They also received total body irradiation of $10 \mathrm{~Gy}$ ( $1000 \mathrm{rads}$ ) or five fractions of $2.5 \mathrm{~Gy}$. The dose to the lung was reduced to 8 or $10 \mathrm{~Gy}$. The dose rate was $7 \mathrm{cGy}(\mathrm{rads}) / \mathrm{min}$. Patients with severe aplastic anaemia were treated with four doses of cyclophosphamide $50 \mathrm{mg} / \mathrm{kg}$ for immunosuppression; two patients also received total body irradiation of $3 \mathrm{~Gy}$. Immediately after transplantation all of the patients were isolated for four weeks in laminar airflow units with total enteral and topical decontamination to prevent infections. All received co-trimoxazole $(30 \mathrm{mg} / \mathrm{kg}$ a day) orally as prophylaxis against Pneumocystis carinii infection. Prophylaxis against graft versus host disease was undertaken with methotrexate or cyclosporin $\mathrm{A}$ and in patients with leukaemia the marrow was also incubated with anti-human thymocytoglobulin. ${ }^{13}$ Details of conditioning and graft versus host disease prophylaxis are given in earlier publications. ${ }^{1814}$

\section{LUNG FUNCTION TESTS}

Before transplantation and one to six months thereafter static and dynamic lung volumes were determined by means of body plethysmography (Fenyves and Gut) and the following indices were determined: inspiratory vital capacity (VC), residual volume (RV), thoracic gas volume (TGV), total lung capacity (TLC), RV \% TLC, FEV 1, FEV $_{1} \%$ VC, maximal breathing capacity (MBC), airway resistance (Raw), and specific airway resistance (sRaw). Transfer factor for carbon monoxide (TLCO) and transfer coefficient (KCO) were measured by the single breath method. The measurements are given as percentages of the normal values published by Rühle and Matthys $(1976)^{15}$ for static and dynamic lung volumes. The reference values for TLCO were obtained in our own lung function laboratory. ${ }^{16}$

\section{STATISTICAL METHODS}

The measurements before transplantation and those taken one to six months afterwards were grouped together. Group means were compared with Student's $t$ test for dependent and independent random samples, with a significance level of $5 \%$ for the two sided test.

\section{Results}

\section{PATIENTS WITH LEUKAEMIA}

Results obtained in patients with leukaemia are shown in table 2.

Vital capacity was reduced even before bone marrow transplantation and fell significantly $(\mathrm{p}<0.01)$ after transplantation. RV and RV \% TLC were noticeably raised before transplantation and increased significantly afterwards $(\mathrm{p}<0.05$ and 0.01$)$. FEV $_{1}$ fell significantly $(p<0.05)$. sRaw was higher than normal before transplantation but did not rise 
afterwards to any significant degree. Kco was reduced after transplantation, but the reduction did not reach statistical significance. These values show that after transplantation airway obstruction and pulmonary hyperinflation increased even further.

If the three patients with obstructive bronchiolitis after transplantation are excluded from the analysis of the patients with leukaemia, a comparison of values before and after transplantation yields the following: VC fell significantly $(p<0.01)$, RV \% TLC increased significantly $(p<0.01)$, Raw fell significantly $(\mathrm{p}<0.05)$, and TLCO fell significantly $(\mathrm{p}<0.05)$. RV rose and $\mathrm{FEV}_{1}$ fell slightly after transplantation but the changes were not significant.

\section{PATIENTS WITH LEUKAEMIA DEVELOPING OBSTRUCTIVE BRONCHIOLITIS}

Obstructive bronchiolitis after transplantation was associated with acute or chronic graft versus host disease and characterised by increasing dyspnoea, cough, cyanosis, and pulmonary hyperinflation. Histological studies showed extensive obstruction of the lumina of the small bronchi and bronchioles by non- specific granulation tissue or by fibrous scar tissue. The bronchial and bronchiolar walls were so severely inflamed that they were often barely recognisable as such. The lung tissue was scarred over extensive regions (indurated atelectasis) and was emphysematous in other parts.

Of all our patients so far, four patients with chronic and one with acute graft versus host disease developed obstructive bronchiolitis between seven weeks and eight months after transplantation. The chest radiograph in three of the patients showed pronounced pulmonary hyperinflation and recurrent pneumothorax with distinct cutaneous emphysema. The capillary oxygen tensions fell to $50-70 \mathrm{~mm} \mathrm{Hg}$ (6.7-9.3 kPa). Pseudomonas aeruginosa, Proteus mirabilis, non-haemolytic streptococci, Serratia marcescens, Citrobacter freundii, and enterococci were detected in the cultures of sputum or bronchial secretions.

Indices of pulmonary function for three patients (one acute and two chronic myeloid leukaemia) with histologically established obstructive bronchiolitis after transplantation in conjunction with chronic

Table 2 Results of lung function tests before and after bone marrow transplantation in patients with leukaemia and severe aplastic anaemia (mean values with standard deviation in parentheses)

\begin{tabular}{|c|c|c|c|c|c|c|}
\hline & \multirow[t]{2}{*}{$n$} & \multicolumn{2}{|c|}{ Leukaemia \% of normal values } & \multirow[t]{2}{*}{$n$} & \multicolumn{2}{|c|}{ Aplastic anaemia $\%$ of normal values } \\
\hline & & Before & After & & Before & After \\
\hline $\begin{array}{l}\text { VC } \\
\text { TGV } \\
\text { RV } \\
\text { RV \% TLC } \\
\text { TLC } \\
\text { FEV }_{1} \\
\text { FEV }_{1} \% \text { VC } \\
\text { Raw } \\
\text { sRaw } \\
\text { KCO }\end{array}$ & $\begin{array}{l}21 \\
18 \\
18 \\
18 \\
18 \\
21 \\
21 \\
17 \\
17 \\
10\end{array}$ & $\begin{array}{r}77(13) \\
123(24) \\
174(55) \\
177(47) \\
96(15) \\
88(17) \\
114(12) \\
122(22) \\
156(36) \\
77(12)\end{array}$ & $\begin{array}{l}66(16)^{*} \\
152(69) \\
254(138)^{* *} \\
228(61)^{*} \\
104(32) \\
75(25)^{* *} \\
108(18) \\
123(79) \\
187(153) \\
69(17)\end{array}$ & $\begin{array}{l}5 \\
4 \\
4 \\
4 \\
4 \\
5 \\
5 \\
4 \\
4 \\
2\end{array}$ & $\begin{array}{c}90(5) \dagger \\
161(23) \\
253(67) \dagger \\
192(37) \ddagger \\
127(11) \\
109(14) \ddagger \\
122(15) \\
82(40) \\
125(44) \ddagger \\
56 \dagger\end{array}$ & $\begin{array}{c}92(4) \\
164(60) \\
237(126) \\
180(42) \\
126(28) \\
118(17) \\
126(19) \\
88(38) \\
116(55) \\
73\end{array}$ \\
\hline
\end{tabular}

${ }^{*} \mathrm{p}<0.01$ for difference between values before and after transplantation.

$* * p<0.05$ for differences between values before and after transplantation.

$t_{p}<0.001$ for difference before transplantation between patients with leukaemia and with aplastic anaemia.

$\pm \mathrm{p}<0.01$ for difference before transplantation between patients with leukaemia and with aplastic anaemia.

VC-vital capacity; TGV-thoracic gas volume; RV-residual volume; RV \% TLC-RV as \% of total lung capacity; TLC-total lung capacity; Raw-airways resistance; sRaw-specific airways resistance; Kco-transfer coefficient.

Table 3 Results of lung function tests in three patients with leukaemia treated by bone marrow transplantation and developing histologically proved obstructive bronchiolitis (included in table 2) (percentages of predicted normal values)

\begin{tabular}{|c|c|c|c|c|c|c|c|c|}
\hline \multirow[t]{2}{*}{$\begin{array}{l}\text { Patient } \\
\text { Diagnosis/age (y) }\end{array}$} & \multicolumn{2}{|c|}{$\begin{array}{l}A(N o 12) \\
A M L / 27\end{array}$} & \multicolumn{2}{|c|}{$\begin{array}{l}B(\text { No 28) } \\
C M L / 15\end{array}$} & \multicolumn{2}{|c|}{$\begin{array}{l}C(N o 47) \\
C M L \text { acc } / 22\end{array}$} & \multicolumn{2}{|c|}{ Mean values } \\
\hline & Before & After & Before & After & Before & After & Before & After \\
\hline $\begin{array}{l}\text { VC } \\
\text { TGV } \\
\text { RV } \\
\text { RV \% TLC } \\
\text { TLC } \\
\text { FEV }_{1} \\
\text { FEV } \% \text { VC } \\
\text { Raw }_{\text {sRaw }} \\
\text { KCo }\end{array}$ & $\begin{array}{r}65 \\
130 \\
206 \\
203 \\
99 \\
61 \\
94 \\
123 \\
160 \\
-\end{array}$ & $\begin{array}{r}50 \\
142 \\
263 \\
253 \\
103 \\
44 \\
89 \\
228 \\
323 \\
58\end{array}$ & $\begin{array}{l}103 \\
148 \\
130 \\
110 \\
106 \\
133 \\
130 \\
107 \\
159 \\
-\end{array}$ & $\begin{array}{r}49 \\
198 \\
316 \\
277 \\
103 \\
40 \\
81 \\
362 \\
715 \\
65\end{array}$ & $\begin{array}{r}67 \\
90 \\
160 \\
184 \\
87 \\
79 \\
117 \\
139 \\
126 \\
59\end{array}$ & $\begin{array}{r}59 \\
121 \\
227 \\
240 \\
95 \\
55 \\
92 \\
167 \\
201 \\
60\end{array}$ & $\begin{array}{r}78 \\
123 \\
165 \\
166 \\
97 \\
91 \\
114 \\
123 \\
148 \\
\end{array}$ & $\begin{array}{r}53 \\
154 \\
269 \\
257 \\
100 \\
46 \\
87 \\
252 \\
413 \\
61\end{array}$ \\
\hline
\end{tabular}

Abbreviations as in tables 1 and 2. 
graft versus host disease are shown in table 3 . The values before and after transplantation showed an increase in pulmonary hyperinflation and airway obstruction in all of the patients; there was a decrease in $\mathrm{VC}, \mathrm{FEV}_{1}$, and $\mathrm{FEV}_{1} \% \mathrm{VC}$, an increase in RV, and RV \% TLC and an extreme elevation in sRaw. Measurements of $\mathrm{KCO}$ were made after transplantation but not before. The results were clearly lower than normal.

\section{PATIENTS WITH SEVERE APLASTIC ANAEMIA}

(table 2)

RV and RV \% TLC were appreciably raised even before transplantation and did not fall substantially afterwards. The other indices showed no change, suggesting that pulmonary hyperinflation was present before and after transplantation with no change.

COMPARISON BETWEEN PATIENTS WITH

LEUKAEMIA AND WITH SEVERE APLASTIC

ANAEMIA

The following pre-transplantation measurements (table 2) were significantly lower in patients with leukaemia than in those with severe aplastic anaemia: VC, RV (p < 0.001), RV \% TLC (p < 0.01), FEV 1 ( $\mathrm{p}<0.01)$, and KCO $(\mathrm{p}<0.001)$. sRaw was significantly higher $(p<0.01)$. Thus before transplantation patients with leukaemia had less severe pulmonary hyperinflation but more severe airway obstruction than those with severe aplastic anaemia. There was no difference in TLCo between the two groups before transplantation. After transplantation pulmonary hyperinflation and obstruction increased further in the leukaemic patients, which made the differences between the two groups even greater. Comparison between the two groups of the posttransplantation values of VC, RV, RV \% TLC, and sRaw showed highly significant differences $(\mathrm{p}<0.001)$.

\section{Discussion}

The present study shows a striking difference between patients with leukaemia and those with severe aplastic anaemia. Even before bone marrow transplantation the leukaemic patients had more pulmonary hyperinflation with greater than normal residual volume and lower than normal vital capacity. Specific airway resistance was likewise increased. These findings indicate the presence of bronchial obstruction, the cause of which has not been established. One conceivable cause could be the cytostatic chemotherapy ${ }^{17}$ to which all of the patients with leukaemia were subjected in the course of primary treatment. Usually, however, chemotherapy has been cited as the cause of interstitial pulmonary changes with subsequent fibrosis and restrictive losses in function. ${ }^{18}$ In contrast to the patients with severe aplastic anaemia, the leukaemic patients showed significant lowering of VC, RV, RV \% TLC, and KCo before transplantation, while sRaw was significantly raised. In contrast to the leukaemic patients, the patients with aplastic anaemia appeared to have appreciable pulmonary hyperinflation but no substantial obstruction. After transplantation the leukaemic patients' VC and FEV 1 decreased while RV and RV \% TLC increased significantly. The changes in lung volumes are the result of a further increase in bronchial obstruction. Similar findings after transplantation have been reported by others. ${ }^{56}$ The comparison with the patients with aplastic anaemia shows the differences that already existed before transplantation, as well as significantly raised sRaw and significantly lowered $\mathrm{KCO}$ in patients with leukaemia. One important factor leading to this difference is likely to be the total body irradiation given to the leukaemic patients before transplantation, since the other measures connected with transplantation were similar for the two groups of patients. Possibly total body irradiation causes damage to the alveolarendothelial membrane, which could contribute to reduction in transfer factor-as has been postulated by other authors who have found lowered TLCo after transplantation. ${ }^{1112}$

So far, we have been able to test lung function in three patients with obstructive bronchiolitis after transplantation. All three patients showed changes indicating an obliterative process in the small airways. Similar changes have been found by others. $^{9101920-23}$ All of the patients observed in Tübingen with obstructive bronchiolitis (five patients-two of them are not mentioned in this study) also had acute or chronic graft versus host disease, an association confirmed by others. ${ }^{7-1019-23}$ In a large scale series in Seattle no association between graft versus host disease and obstructive lung disease was found, but the patients with features of obstructive defects of lung function examined more than four years after bone marrow transplantation usually also had chronic graft versus host disease. ${ }^{521}$ Probably we need to distinguish between the moderate obstruction after transplantation that usually occurs in leukaemic patients and obstructive bronchiolitis, which can be histologically established and which according to all the data so far published occurs only in conjunction with graft versus host disease. The pathogenesis of these latter bronchial and bronchiolar obstructions is still unclear. A connection with chronic graft versus host disease is likely since this late complication triggers a fibrotic process in several organs and shows some similarities to autoimmune diseases, ${ }^{24}$ such as systemic sclerosis, sys- 
temic lupus erythematosus, and Sjögren's disease. Obstructive bronchiolitis can also occur as a complication of these autoimmune diseases. ${ }^{17}$

On the basis of these results we conclude that patients with leukaemia receiving total body irradiation develop obstructive ventilatory disorders. The lung function of patients with severe aplastic anaemia, by contrast, is only slightly impaired in the first six months after transplantation. Particular attention must be paid to the development of bronchiolar obstruction in patients with graft versus host disease, since obstructive bronchiolitis may be a manifestation of graft versus host disease. In view of the poor prognosis of this complication, immediate treatment with immunosuppressants is indicated in such cases. $^{791618}$

\section{References}

1 Link H, Ostendorf $\mathrm{P}$, Wernet $\mathrm{P}$, et al. Pulmonary complications after allogeneic bone marrow transplantation. The Tübingen experience. Exp Hematol 1984;12,suppl 15:21-2.

2 Bortin MM, Gale RP, Kay HEM, Rimm AA. Bone marrow transplantation for acute myelogenous leukemia. Factors associated with early mortality. JAMA 1983;249:1166-75.

3 Buckner CD, Meyers JD, Springmeyer SC, et al. Pulmonary complications of marrow transplantation. Review of the Seattle experience. Exp Hematol 1984;12,suppl 15:1-5.

4 Winston DJ, Ho WG, Champlin RE, Gale RP. Infectious complications of bone marrow transplantation. Exp Hematol 1984;12:205-15.

5 Springmeyer SC, Flournoy N, Sullivan KM, Storb R, Thomas ED. Pulmonary function changes in long-term survivors of allogeneic marrow transplantation. In: Gale $\mathrm{RP}$, ed. Recent advances in bone marrow transplantation. New York: AR Liss, 1983:343-53.

6 Serota FT, August CS, Koch PA, Fox W, D'Angio GJ. Pulmonary function in patients undergoing bone marrow transplantation. Med Pediatr Oncol 1984;12:137-43.

7 Kurzrock R, Zander A, Kanojia M, et al. Obstructive lung disease after allogeneic bone marrow transplantation. Transplantation 1984;37:156-60.

8 Link H, Reinhard U, Niethammer D, Krüger GRF, Waller HD, Wilms K. Obstructive ventilation disorder as a severe complication of chronic graft versus host disease after bone marrow transplantation. Exp Hematol 1982;10,suppl 10:92-3.

9 Roca J, Granena A, Rodriguez-Roisin R, Alvarez P,
Agusti-Vidal A. Fatal airway disease in an adult with chronic graft versus host disease. Thorax 1982;37:77-8.

10 Wyatt SE, Nunn P, Hows JM, et al. Airways obstruction associated with graft versus host disease after bone marrow transplantation. Thorax 1984;39:887-94.

11 Sørensen PG, Ernst P, Panduro J, Møller J. Reduced lung function in leukemia patients undergoing bone marrow transplantation. Scand J Haematol 1984;32:253-7.

12 Depledge MH, Barrett A, Powles RL. Lung function after bone marrow grafting. Int J Radiat Oncol Biol Phys 1983;9:145-51.

13 Rodt H, Kolb HJ, Netzel B, et al. Effect of anti-T-cell globulin on GvHD in leukemia patients treated with BMT. Transplant Proc 1981;13:257-61.

14 Link H, Wilms K, Meyer P, et al. Bone marrow transplantation for acute leukemia in remission. The Tübingen experience. Exp Hematol 1982;10,suppl 10:87.

15 Rühle KH, Matthys $H$. Kritische Auswahl von Sollwerten für ein Computer-Programm zur RoutineLungenfunktionsdiagnostik. Pneumonologie 1976;153: 223-33.

16 Keimer R. Neue Normalwerte für die DLCO-SB bei Kindern und Erwachsenen ermittelt mit einer vollautomatischen Meßvorrichtung. Medical dissertation, University of Tübingen, 1975.

17 Epler GR, Colby TV, McLeod TC, Carrington CB, Gaensler EA. Bronchiolitis obliterans organizing pneumonia. N Engl J Med 1985;312:152-8.

18 Collis $\mathbf{C H}$. Lung damage from cytotoxic drugs. Cancer Chemother Pharmacol 1980;4:17-27.

19 Johnson FL, Stokes DC, Ruggiero M, Dallapozza L, Callihan TR. Chronic obstructive airways disease after bone marrow transplantation. J Pediat 1984;105:370-6.

20 Rosenberg ME, Vercellotti GM, Snover DC, Hurd D, McGlave P. Bronchiolitis obliterans after bone marrow transplantation. Am J Hematol 1985;18:325-8.

21 Ralph DD, Springmeyer SC, Sullivan KM, Hackman RC, Storb R, Thomas ED. Rapidly progressive air-flow obstruction in marrow transplant recipients-possible association between obliterative bronchiolitis and chronic graft versus host disease. Am Rev Respir Dis 1984;129:641-4.

22 Atkinson K, Bryant D, Biggs J, Concannon A, Dodds A Obstructive airways disease: a rare but serious manifestation of chronic graft-versus-host disease after allogeneic marrow transplantation in humans. Transplant Proc 1984;16:1030-3.

23 Bradstock KF, Coles R, Despas P, Tivver K, Koutts J Hughes WG. Fatal obstructive airways disease after bone marrow transplantation. Transplant Proc 1984;16:1034-6.

24 Sullivan KM, Shulman HM, Storb R, et al. Chronic graft-versus-host disease in 52 patients: adverse natural course and successful treatment with combination immunosuppression. Blood 1981;57:267-76. 